Western University Scholarship@Western

Centre for the Study of International Economic

Centre for the Study of International Economic

Relations Working Papers

Relations

1985

\title{
A North-South Model of International Justice
}

Elias Dinopoulos

Ian Wooton

Follow this and additional works at: https://ir.lib.uwo.ca/economicscsier_wp

Part of the Economics Commons

Citation of this paper:

Dinopoulos, Elias, Ian Wooton. "A North-South Model of International Justice." Centre for the Study of International Economic Relations Working Papers, 8516C. London, ON: Department of Economics, University of Western Ontario (1985). 
THE CENTRE FOR THE STUDY OF INTERNATIONAL ECONOMIC RELATIONS

WORKING PAPER NO. 8516C

A NORTH-SOUTH MODEL OF

INTERNATIONAL JUSTICE

Elias Dinopoulos

and

Ian Wooton

This paper contains preliminary findings from research work still in progress and should not be auoted without prior approval of the authors.

DEPARTMENT OF ECONOMICS UNIVERSITY OF WESTERN ONTARIO LONDON, CANADA N6A $5 \mathrm{C} 2$

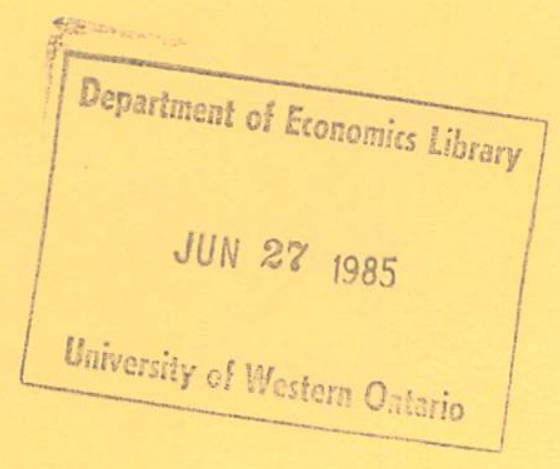


A Borth-South Hodel of

International Justice

\section{Elias Dinopoulos*}

and

Ian Wooton**

June, 1985

*Michigan State University

**University of Western Ontario

Partial funding for this paper was provided by a grant from the Social Sciences and Humanities Research Council of Canada 


\section{IHIRODUCTIOS}

Rawls (1971) has proposed that gains from economic cooperation be shared in a way which maximizes the welfare of the worse-off participant. Mirrlees (1972), Sheshinski (1971) and Phelps (1973) have applied the so-called minimax criterion of economic justice to the problem of wage-income taxation in a closed economy.

In a seminal contribution. Findlay (1983) postulated that the Rawlsian criterion could be easily applied to the economic gains generated by international exchange of commodities. He argued that free trade is not, in general, "just" in that the gains from trade are not distributed with any regard to the relative welfare levels of participating countries. The North-South negotiations can be considered as an attempt to establish an international economic order which will ensure that the distribution of gains from trade is fair. Thus, it is natural to study how the minimax criterion of international distributive justice would modify the level and nature of existing commercial policies and institutions which determine the distribution of gains from trade between North and South.

When the minimax criterion is applied to countries instead of individuals, it implies an additional constraint to the distribution of the gains from trade. Since any country (as opposed to any individual) can survive without trade, in order to induce countries to cooperate the minimax criterion must guarantee the autarky welfare level for each country. Thus, in a North-South model it is possible that the North enjoys a higher welfare level than the South even if the latter gets all the gains from trade.

In this paper, a model of North-South trade is developed. Following Findlay and Wilson (1984), the North is endowed with the means to produce an intermediate product which can be termed "technology" and augments the 
productive abilities of the factors employed in the production of the other good, which can be thought of as a composite consumer good. The South produces only the composite consumer good, but it can increase its production by importing "technology" services from the North. An alternative interpretation of the present model could suggest that the intermediate product represents bureaucracy or government, in the sense of Findlay and Wilson (1984), which is only produced in the North. The pattern of trade, then, is consistent with the North-South period of colonialism.

The major findings of the paper are that "just" trade occurs when the South receives all the gains from trade (or when the welfare levels of both regions are equalized). Free trade and the imposition of the optimal tariff by the South do not meet the minimax criterion. When the South chooses a combination of a tariff and a transfer from the North there are two possible results. If the transfer given to the South does not influence the labour endowment of the North, then free trade and a transfer are the optimal policies satisfying the minimax criterion. However, if the transfer is financed through wage-income taxation which reduces the aggregate labour supply of the North, then a transfer plus a tariff is the optimal policy maximizing the welfare of the South.

The remainder of the paper is as follows: Section 2 develops the technology of the two countries and characterizes the free trade equilibrium. Section 3 introduces the notion of international economic justice and determines how a more "just" allocation of the gains from trade might be made. The paper terminates with section 4 which contains conclusions and suggestions for further research. 


\section{THB EODEL}

There are two countries in the world, the Morth (W) and the South (S) whose supply sides are described below.

\subsection{The Borth}

The North produces two goods, an intermediate product $(T)$ and a final consumption good (C). The intermediate good, which may be considered to be technical skills or government services, is produced from the services of labour and a sector-specific resource (K) according to a neoclassical production function exhibiting constant returns to scale,

$$
T=Z\left(L_{T}, K\right) \text {. }
$$

Let the first and second partial derivatives of the $Z$ function with respect to labour be designated $Z^{\prime}$ and $Z^{\prime \prime}$, respectively, where

$$
\begin{aligned}
& Z^{\prime}>0 \\
& Z^{\prime \prime}<0 .
\end{aligned}
$$

Note that both factors are essential to produce positive output, hence

$$
\mathrm{Z}(0, \mathrm{~K})=0 \text {. }
$$

Manufacture of the consumption good requires inputs of labour services and the services of the fixed endowment of land $\left(V_{w}\right)$,

$$
C_{\mathrm{V}}=\mathbf{Y}_{\mathrm{U}}\left(\mathrm{L}_{\mathrm{C}}, \mathrm{V}_{\mathrm{U}}\right) \text {, }
$$

where $Y_{W}$ is a neoclassical production function exhibiting constant returns to scale and whose first and second partial derivatives with respect to labour are, respectively,

$$
\begin{aligned}
& Y_{y}^{\prime}>0 \\
& Y_{y}^{\prime \prime}<0 .
\end{aligned}
$$

Output of $\mathrm{C}$ can, however, be augmented by the use of some $T$ in its production process, such that

$$
C_{N}=\lambda_{N}\left(T_{N}\right) Y_{N}\left(L_{C}, V_{N}\right)
$$

where $T_{Y}$ is the quantity of $T$ used in the production of $C$. Let the function 
$\lambda_{\mathrm{W}}$ have the properties $\lambda_{\mathrm{W}}(0)=1$

$$
\begin{aligned}
& \lambda_{W}^{\prime}>0 \\
& \lambda_{u}<0
\end{aligned}
$$

where $\lambda_{W}^{\prime}$ and $\lambda_{W}^{\prime \prime}$ are, respectively, the first and second derivatives of $\lambda_{W}$ with respect to its argument.

Labour is initially considered to be in inelastic supply and freely mobile between the two sectors, such that

$$
L_{T}+L_{C}=\bar{L}_{\mathbf{S}}
$$

where $\mathrm{L}_{\mathrm{H}}$ is the North's labour endowment.

Assuming identical tastes for all agents in the North, utility is maximized when consumption is maximized. For the autarkic economy, this is identical with maximum output of $c, C_{w^{*}}^{*}$ Substituting (1) and (3) into (2),

$$
C_{W}=\lambda_{W}\left(Z\left(\bar{L}_{N}-L_{C}, K\right)\right) Y_{W}\left(L_{C}, V_{W}\right)
$$

Differentiating with respect to the variable term, ${ }_{C}$, yields a first-order condition that the marginal product of labour in both activities be equal,

$$
\lambda_{\mathrm{N}}^{\prime}(\mathrm{T}) \mathrm{Z}^{\prime}\left(\mathrm{L}_{\mathrm{T}}, \mathrm{K}\right) \mathrm{Y}_{\mathrm{N}}\left(\mathrm{L}_{\mathrm{C}}, \mathrm{V}_{\mathrm{N}}\right)=\lambda_{\mathrm{N}}(\mathrm{T}) \mathrm{Y}_{\mathrm{U}}^{\prime}\left(\mathrm{L}_{\mathrm{C}}, \mathrm{V}_{\mathrm{N}}\right)
$$

Suppose now that the North were able to trade some of its $T$ in exchange for imports of $C$. Consider the maximum production of $\mathbf{C}_{\mathbf{N}} \mathbf{g i v e n}$ exports, $\mathbf{T}_{\mathbf{X}}$.

$$
\begin{aligned}
& C_{N}=\lambda_{N}\left(Z\left(L_{N}-L_{C}, K\right)-T_{X}\right) Y_{N}\left(L_{C}, V_{W}\right) \\
& \underset{N}{d C_{N}}=-\lambda_{W}^{\prime} \mathbf{Y}_{N}\left(L_{C}, V_{N}\right)<0
\end{aligned}
$$




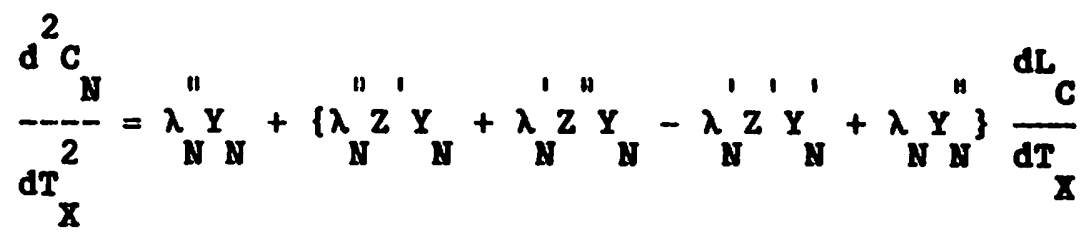

The first term of the last expression, capturing the direct effect, is negative while the second term is positive. Assuming the direct effect dominates, $C_{N}$ is a concave function of $T_{X}$.

At given international terms of trade,

$$
\mathbf{P}=\frac{\mathbf{P}_{\mathrm{T}}}{\mathbf{P}_{\mathrm{C}}}
$$

the North's objective is to maximize

$$
\mathbf{C}=\mathrm{C}_{\mathbf{W}}+\mathrm{C}_{\mathbf{H}}
$$

where $C_{N}$ is determined by (6) and $C_{M}$ are imports of the consumption good such that,

$$
\mathbf{C}_{\mathbf{M}}=\mathbf{p} \mathbf{T}_{\mathbf{X}} \text {. }
$$

Thus, substituting (6) and (9) into (8),

$$
C=\lambda_{W}\left(Z\left(L-L_{C}, K\right)-T_{X}\right) Y_{W}\left(L_{C}, V_{W}\right)+P T_{X}
$$

Taking partial derivatives, setting them to zero, and solving yields

$$
p=A\left(L_{C}, T_{Z}\right)=B\left(L_{C}, T_{Z}\right)
$$

where $\quad A\left(L_{C}, T_{X}\right)=\frac{\lambda_{N} Y^{\prime}}{Z^{\prime}}$

and

$$
B\left(L, T_{X}\right)=\lambda_{N}^{\prime} Y_{N}
$$

The equality between $A$ and $B$ is analogous to that in equation (5) and ensures the efficient allocation of labour between sectors. This is shown in Figure 1(a). The absolute value of the slope of the $C_{N}$ function in 
equation (6) with respect to $T_{X}$ is $B$, hence the domestic marginal rate of transformation between $C_{y}$ and $T_{X}$ must, for efficiency, equal the foreign rate of transformation, $p$.

The North's trading equilibrium is illustrated in Figure 1(b). Curve $W\left(T_{X}\right)$ is the graph of equation (6) showing the maximum production of $C_{\mathbb{B}}$ given exports of $T_{\mathbf{X}}$. Production takes place at $F$ with exports of $T$ equal to $O G$ and imports of C equal to ED. Domestic production of the consumption good is $O B$, giving a total consumption of $O D$. The gains from trade for the North may be measured as the increased quantity of consumption good available, equal to $C_{y}^{*}$. Given the convexity assumptions, as $p$, the relative price of $T$, increases, Northern production of $T$ rises and its production of $C$ diminishes while consumption of C rises. Thus the North's of fer curve must, at all prices at which there is trade, have a positive slope. This is because there is no conflict between income and substitution effects--a rising $p$ increases the North's income in terms of $\mathrm{C}$, the only good that is consumed. Thus the North's offer curve has the normal shape with positive elasticity of imports with respect to exports. The slope of a northern trade indifference curve $\left(\operatorname{TIC}_{N}\right)$ is $\lambda_{N}^{\prime} Y^{\prime}$, i.e. $\left.\frac{d C_{X}}{d T}\right|_{C_{N}}=\lambda_{N}^{\prime} Y_{N}$.

\subsection{The South}

The South produces only the consumption good (C) as it has none of the specific capital necessary for the production of $T$. The consumption good is produced using the services of Southern labour $\left(L_{S}\right)$ and land $\left(v_{S}\right)$ according to a neoclassical production function exhibiting constant returns to scale

$$
C_{S}=Y_{s}\left(L_{s} \cdot V_{s}\right)
$$


If the South were able to acquire technology services ( $T_{S}$ ) from the North, this would be used to augment production such that

$$
C_{S}=\lambda_{S}\left(T_{S}\right) Y_{S}\left(L_{S}, V_{S}\right)
$$

where the function $\lambda_{S}$ has the properties

$$
\lambda_{s}(0)=1, \lambda_{s}^{\prime}>0, \lambda_{s}^{\prime \prime}<0
$$

where $\lambda_{s}^{\prime}$ and $\lambda_{s}^{\prime \prime}$ are, respectively, the first and second derivatives of $\lambda_{s}$ with respect to its argument. This relationship between $C_{S}$ and $T_{S}$ is illustrated in Figure $2(a)$.

Suppose that the technology services were available from the Uorth only through trade. Thus the South would export units of the consumption good $\left(C_{\mathbf{x}}\right)$ in exchange for imports of technology $\left(T_{M}\right)$. At given international relative prices, $p$, the south maximizes its consumption,

$$
C=\lambda_{S}\left(T_{M}\right) Y_{S}\left(L_{S}, V_{S}\right)-C_{X}
$$

where $\quad \mathrm{c}_{\mathrm{X}}=\mathrm{pT}_{\mathbf{H}}$.

substituting (15) into (14) yields

$$
C=\lambda_{S}\left(T_{M}\right) Y_{S}\left(L_{S}, V_{S}\right)-P T_{M}
$$

The first-order condition for maximum consumption is

$$
p=\lambda_{s}^{\prime} Y_{s}
$$

Thus the domestic rate of transformation between $C_{S}$ and $T_{H}$ mast equal the foreign rate of transformation, as is shown in Figure $2(b)$ where $S\left(T_{M}\right)=$ $\lambda_{S}\left(T_{M}\right) Y_{S}\left(L_{S}, V_{S}\right)$. Note also that $\lambda_{S}^{\prime} Y_{S}$ is the slope of a southern trade indifference curve ( TIC $_{S}$ ),

i.e. $\frac{\mathrm{d}}{\mathrm{dT}} \mid=\lambda_{\mathrm{M}}^{\prime} \mathrm{Y}_{S}>0$. Production takes place at $D$ using OJ imported

technology. Of the $\mathrm{OH}$ domestic production $\mathrm{FH}$ is exported, leaving of for domestic consumption. The gains from trade are therefore $\mathrm{C}_{\mathrm{S}}^{\star} \mathrm{F}$.

The free-trade offer curve of the South is

$$
C_{\mathrm{X}}=\mathrm{pr}
$$


where $p=\lambda_{s}^{\prime} Y_{s}$

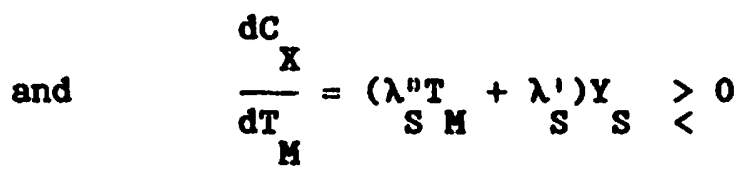

\subsection{Free-Trade Bquilibrium}

The quantities of consumption good and technology traded between the North and the South under free trade are illustrated in Figure $3(a)$. Curve $O C_{\mathrm{B}}$ represents the North's offer curve and $\mathrm{OC}_{\mathrm{s}}$ is the South's offer curve which is the graph of equation (18). Combining equations (11) and (17) yields the free-trade condition that

$$
p^{F T}=\frac{\lambda_{Y^{Y}}^{\prime}}{Z^{\prime}}=\lambda_{N^{\prime}}^{\prime} Y_{N}=\lambda_{S}^{\prime} Y_{S}
$$

i.e. labour is allocated efficiently between activities in the North and the marginal productivities of technology are identical across nations. Horeover, equation (19) implies that at the free-trade equilibrium point the trade indifference curves (not shown in Figure $3(a)$ ) are tangent to each other.

Figure $3(b)$ incorporates Figures $1(b)$ and $2(b)$. The trade triangle is DEF, EF consumption good being exported by the North in exchange for DE of technology. The gains from trade for North and South are $C_{g^{*}} D$ and $C_{s}^{*}$ respectively. Sotice that with free-trade the gains from trade are shared by both countries.

\section{IMTERRATIOMAL JUSTICE}

Consider a free-trade equilibrium where the per capita income of the South is considerably below that of the North. The North's per capita income will be higher even under assumptions of identical production functions, due 
to its sole ownership of the factor $K$, essential in the production of $T$. According to a Rawlsian concept of social justice, the distribution of the gains from trade should be such as to maximize the minimum per-capita utility and therefore free trade is not "just" [see Findlay (1982) for conditions under which free trade may result in a just distribution].

The next two sections shall examine policies, potentially available to the South, that may yield a more just distribution between countries.

\subsection{Tariff Policy}

Denote the North's free-trade offer curve by $C_{M}=p\left(T_{X}\right) T_{X}$. Now $\frac{d p}{d T} \equiv p^{\prime}>0$, and so the South has monopoly power in trade. Suppose now that the South uses a tariff in an attempt to capture the gains from trade from a passive (i.e. not tariff-imposing) North. Thus the South maximizes its consumption,

$$
C_{S}=\lambda_{S}\left(T_{H}\right) Y_{S}-C_{X}
$$

such that $T_{M}=T_{X}$ and $C_{X}=C_{M}$. First-order conditions yield

$$
\lambda_{X}^{\prime} Y_{S}=p+p^{\prime} T_{u^{\prime}}
$$

at the trading equilibrium, the slope of the southern TIC is equal to the slope of the northern offer curve. Figures $4(a)$ and $4(b)$ illustrate the consequences of this tariff policy. Consider Figure $4(a)$ first. Given the shape of North's offer curve, the South's imposition of the optimal tariff reduces the volume of trade in both commodities from oc to of for technology and from $O b$ to $O e$ for the consumption good. Thus, the terms of trade for the South improve from $p^{F T}$ to $p^{O T}$ and the welfare of the South increases. 
World production is inefficient because marginal rates of transformation are not equalized internationally. Figure $4(\mathrm{~b})$ illustrates the South's optimal tariff equilibrium using the production possibilities technique. Note that the North still achieves a higher consumption level than it would in autarky.

\subsection{Rawlsian Trade and Transfers}

Consider now the situation in which, in addition to a tariff, the south receives a transfer $t$ from the North. ${ }^{1}$ The question then is what the optimal policy is (in terms of a combination of a tariff and a transfer) that maximizes the welfare of the South subject to the constraint that the welfare of the North is neither less than that of the South nor less than it was in autarky. Assume that the transfer $\tau$, expressed in units of the consumption good is financed through taxation in the North. Two forms of taxation are considered.

Firstly, suppose that the tax is levied on the returns to capital $k$ and land $v_{v}$, both of which are supplied inelastically. Thus the objective for the South is to maximize

$$
C_{S}=\lambda_{S}\left(T_{M}\right) Y_{S}-P\left(T_{M}\right) T_{M}+T
$$

such that

$$
C_{N}=\lambda_{N} Y_{N}+p\left(T_{M}\right) T_{H}-T \geq c_{W}^{*} \text {. }
$$

First-order conditions yield

$$
\begin{aligned}
\frac{\lambda_{U Y} Y^{\prime}}{Z^{\prime}} & =\lambda_{W^{\prime}} Y_{W}=\lambda_{S}^{\prime} Y_{S} \\
G_{N} & =G_{Y}^{*}
\end{aligned}
$$


which is the condition for free-trade and efficient technology allocation of equation (19). In other words, the optimal policy is free trade (thereby maximizing world output of the consumption good) combined with a transfer of the Worth's gains from trade to the South, $\tau_{1}=C_{\mathrm{N}}^{F T}-C_{\mathrm{W}}^{*}$.

This redistribution is illustrated in Figures $5(a)$ and $5(b)$. In the offer-curve diagram of Figure 5(a) Oc of technology (the free-trade volume) is exported from Worth to South in exchange for Ob consumption good imports. However bh of this is transferred back leaving the Morth with effectively only Oh consumption good, making it indifferent between this exchange and no trade whatsoever--thus point $B$ is on the North's autarkic trade indifference cuve, $\operatorname{TIC}_{\mathbb{N}}^{A}$, while the South is on $\operatorname{TIC}_{S}^{R}$. Figure $5(\mathrm{~b})$ shows the North trading FE technology services in exchange effectively for FH units of consumption good, which exactly compensates for the cost of production. The South uses its technology imports to increase production by $\mathrm{C}_{s}^{\star} \mathrm{H}$ which, after its exports net of the transfer, gives it a consumption gain of $C_{s}^{\star} F$.

Secondly, suppose now that the transfer is financed through wage taxation in the North. Following a variation of Sheshinski (1972), suppose that the North is composed of identical individuals whose utility depends on leisure and consumption. Then under standard assumptions, wage-income taxation reduces the supply of labour. Thus the labour endowment of the North, $L_{Y}$, will be a decreasing function of the transfer $\tau$.

The Rawlsian transfer should, under these circumstances, be that transfer which, together with any tariff imposed by the South, leaves the North at the same level of utility as it enjoyed in autarky. For analytic ease, a less sophisticated transfer is considered here--that which maintains the North's pre-trade per-capita consumption level. ${ }^{2}$ In this case the South again maximizes its consumption, by its choice of tariff and transfer (as in equation (22)), but subject now to the restriction that 


$$
C_{W}=\lambda_{Z}\left(Z\left(L_{N}(\tau)-L_{C}, K\right)-T_{M}\right) Y_{W}\left(L_{C}, V_{W}\right)+P\left(T_{M}\right) T_{M}-\tau \geq C_{W}^{*}
$$

This yields the first-order condition:

$$
\lambda_{S}^{\prime} Y_{S}-\lambda_{W}^{\prime} Y_{N}=\left(-\lambda_{N}^{\prime} Y_{W} Z^{\prime} \frac{d L}{d \tau}\right)\left(p+p^{\prime} T_{H}-\lambda_{S}^{\prime} Y_{S}\right)
$$

Except in particular circumstances, noted below, the optimal tariff for the South is not zero. Were labour unresponsive to the taxation $\left(i . e . d L_{\mathrm{V}} / d \tau=0\right.$ ) or were the South insufficiently large to have monopoly power in trade (i.e. $p^{\prime}=0$ ), then the first-order condition becomes the same as that for free-trade (equation (19)). In all other cases the optimum policy consists of a combination of a tariff plus transfer, the former being less than the optimal tariff examined in section 3.1 and the latter being less than that required when the labour endowment of the North is independent of the transfer.

To see this, assume the contrary, that is, the South follows a free-trade policy and so $\lambda_{S}^{\prime} Y_{S}=\lambda_{Y}^{\prime} Y_{Y}$. Then, equation (26) implies that $p+p^{\prime} T_{S}=\lambda_{S}^{\prime} Y_{S}=\lambda_{W}^{\prime} Y_{W}$. This means that the slope of North's offer curve is equal to the slope of its trade indifference curve which implies that $P^{\prime}=0$. In other words, if $\frac{d L}{d \tau}<0$, then only if the South does not have monopoly power in trade is the optimal policy free-trade plus a transfer. With symmetric reasoning we can exclude very easily the possibility that the South would impose the optimal tariff. Thus, we conclude that in general, when $\frac{d L}{d \tau}<0$ both sides of equation (26) will be positive. 
This implies that the optimal amount of technology services imported by the South would be less than the free trade level but greater than the level corresponding to the optimal tariff in section 3.1. Moreover, this means that the transfer $\tau_{2}$ under this policy will be necessarily less than $\tau_{1}$ the optimal transfer when $\frac{d L}{d \tau}=0$. Notice also, that since the North enjoys the same level of consumption as in autarky in both situations, when dL $\frac{W}{d \tau}<0$ the world's production of the consumer good is not efficient. Thus, the South achieves a lower welfare level than under the situation of $\frac{d}{d \tau}=0$. In terms of Figure $5(a)$, when the transfer $\tau$ is financed through wage-income taxation, the higher the transfer $\tau$, the more the North's trade-indifference curves shift northwest.

\section{COMCLUSIOWS}

In a model of North-South trade, in which the North is the sole producer of an output-augmenting technology, it was demonstrated that free trade is not "just", in the sense that it does not meet the Rawlsian criterion with respect to distribution of the gains from trade.

Alternative trading schemes were then analyzed to determine whether they were more "just". It was shown that the imposition of the optimal tariff by the South increases its share of the gains from trade and it is "closer" to the Rawlsian goal than free trade, especially when the other commercial policy instruments are absent. However the North does still receive some of the benefits from trade and world production is diminished. 
When, in addition to preferential terms of trade, a transfer from Borth to South is introduced which reduces the supply of labour in the Worth, then a combination of a tariff plus a transfer allows the South to receive all the gains from trade. Finally, when the transfer from North to South is financed in a lump-sum fashion, then free-trade and the appropriate transfer permit the South to obtain all the gains from trade without diminishing the world production. This policy satisfies the Rawlsian criterion and dominates all the previous ones in terms of maximizing the welfare of the South. 


\section{FOOTHOTES}

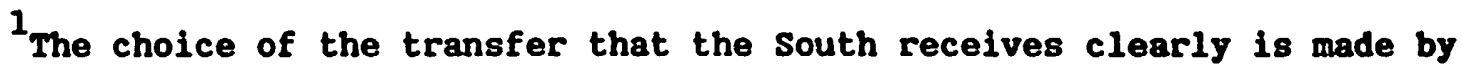
the North and hence is not a direct policy instrument of the South. However it is assumed here that the North is motivated by a "sense of justice" to give the South whatever transfer it desires so long as the North fares no worse in its trading than it did in autarky. Thus the transfer becomes, indirectly, a policy instrument of the South.

${ }^{2}$ The utility of the North does, in fact, increase. The taxation induces more leisure while the consumption level is maintained. The "true" Rawlsian transfer cum tariff, such that the North's utility remains constant, must then be more severe than that determined here. 


\section{REFBREYCES}

Arrow, K. J., (1973), "Rawls Principle of Just Saving," Swedish Journal of Economics, PP. 323-35.

Arrow, K. J., (1973), "Some Ordinalist-Utilitarian Notes on Rawls' Theory of Justice," Journal of Philosophy, pp. 245-63.

Findlay, R., (1982), "International Distributive Justice: A Trade Theoretic Approach," Journal of International Economics, pp. 1-14.

Findlay, R. and J.D. Wilson, (1984), "The Political Bconomy of Leviathan," Institute for International Bconomic Studies, University of Stockholm, Seminar Paper No. 285.

Mirrlees, J. A., (1971), "An Exploration in the Theory of Optimal Income Taxation," Review of Economic Studies, pp. 175-208.

Phelps, E. S., (1973), "Taxation of Wage Income for Economic Justice," Quarterly Journal of Economics, pp. 331-54.

Rawls, J., (1971), A Theory of Justice, Harvard University Press.

Sheshinski, B. (1972), "The Optimal Linear Income Tax," Review of Bconomic Studies, July. 
FIGURE 1 (a)
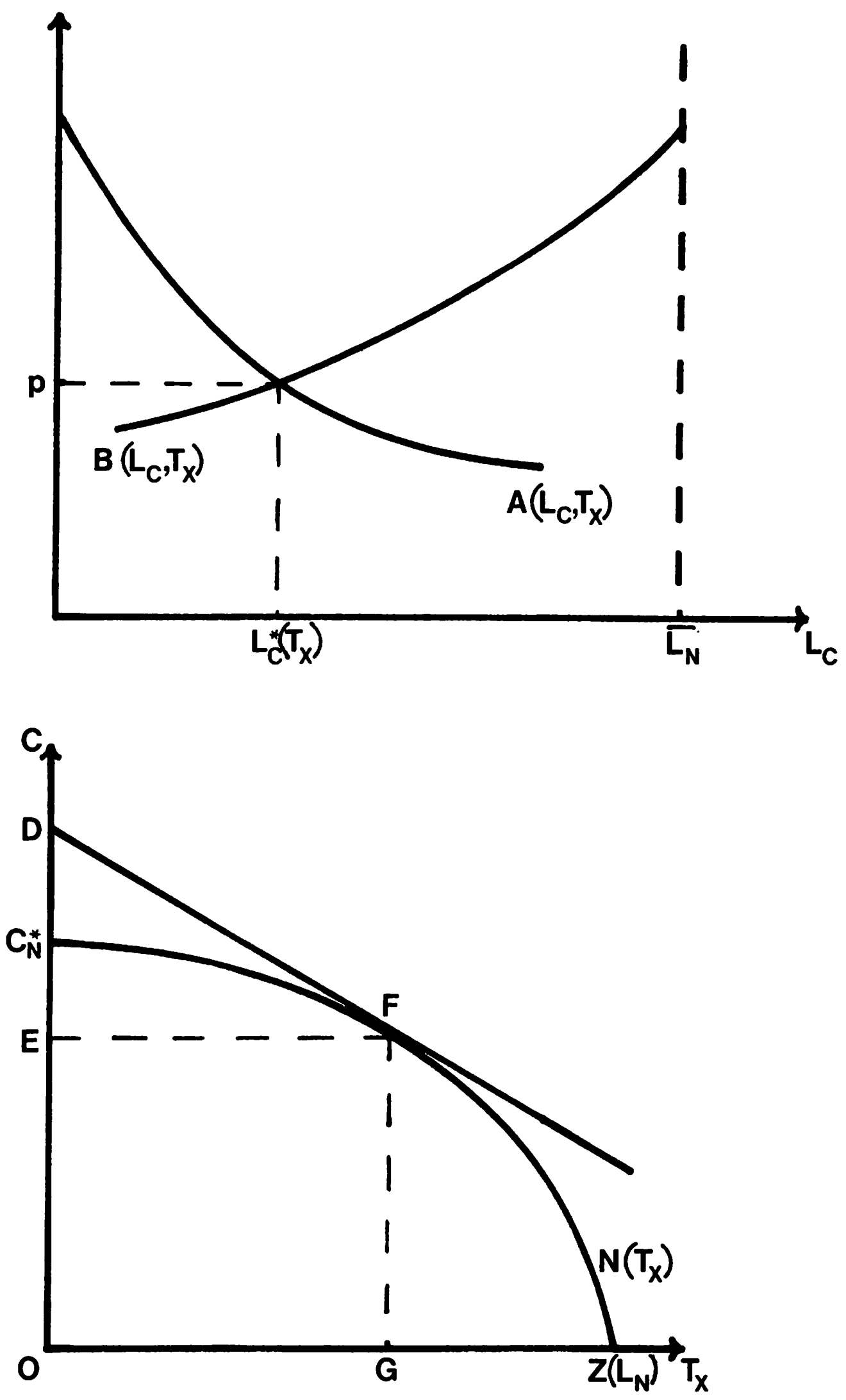

FIGURE 1(b) 
FIGURE 2(a)
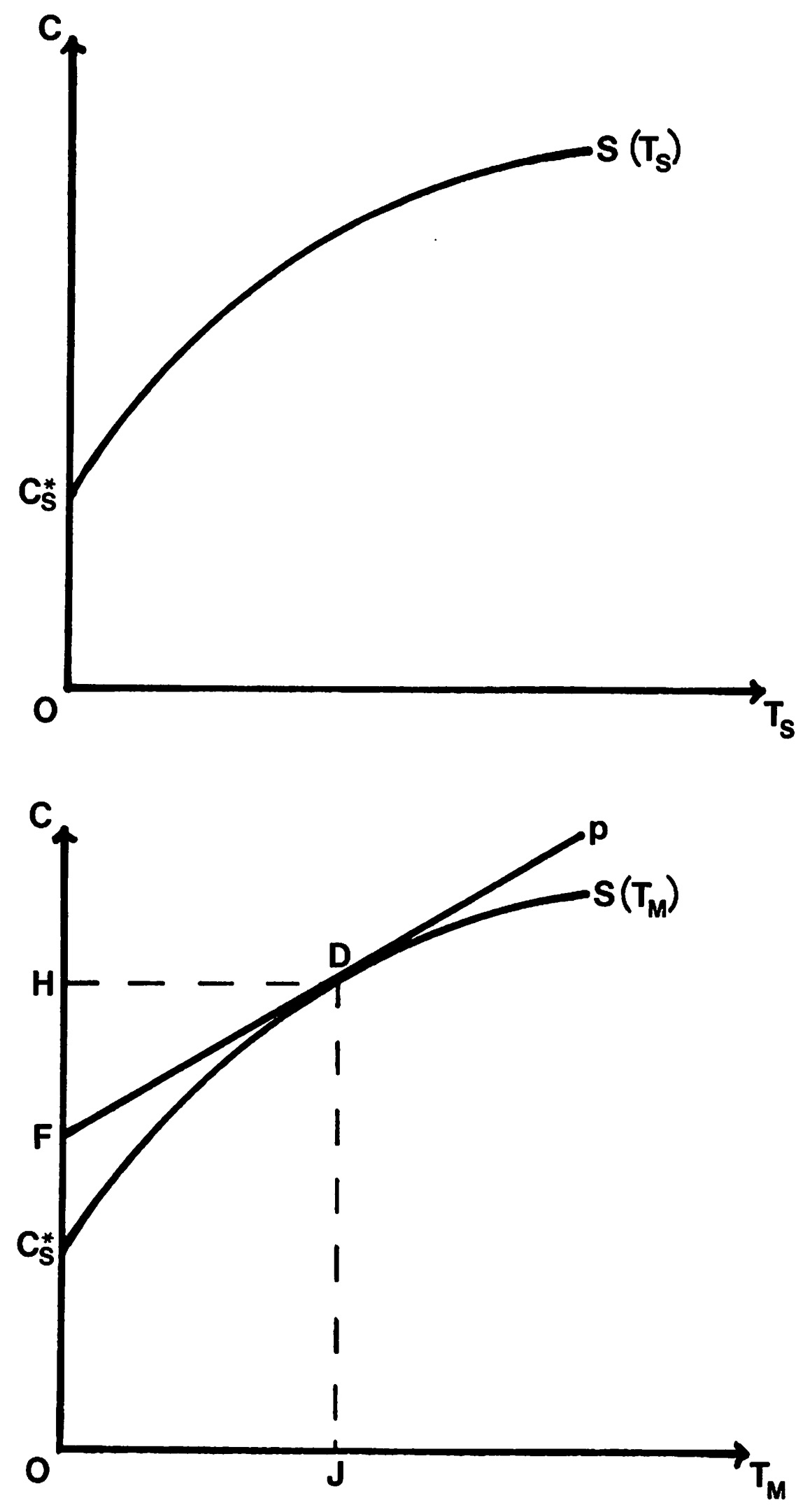

FIGURE 2(b) 
FIGURE 3(a)
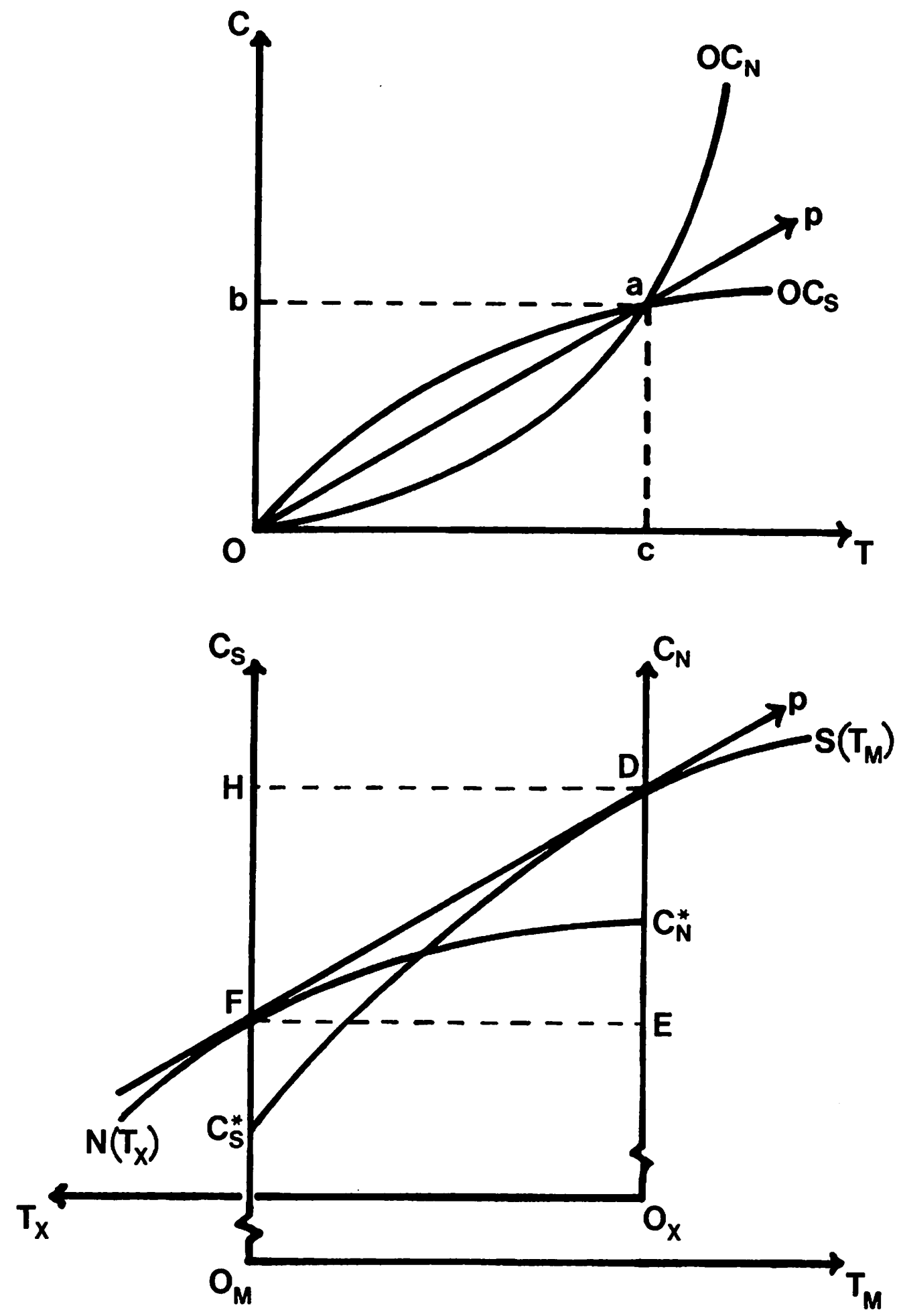

FIGURE 3(b) 
FIGURE $4(a)$
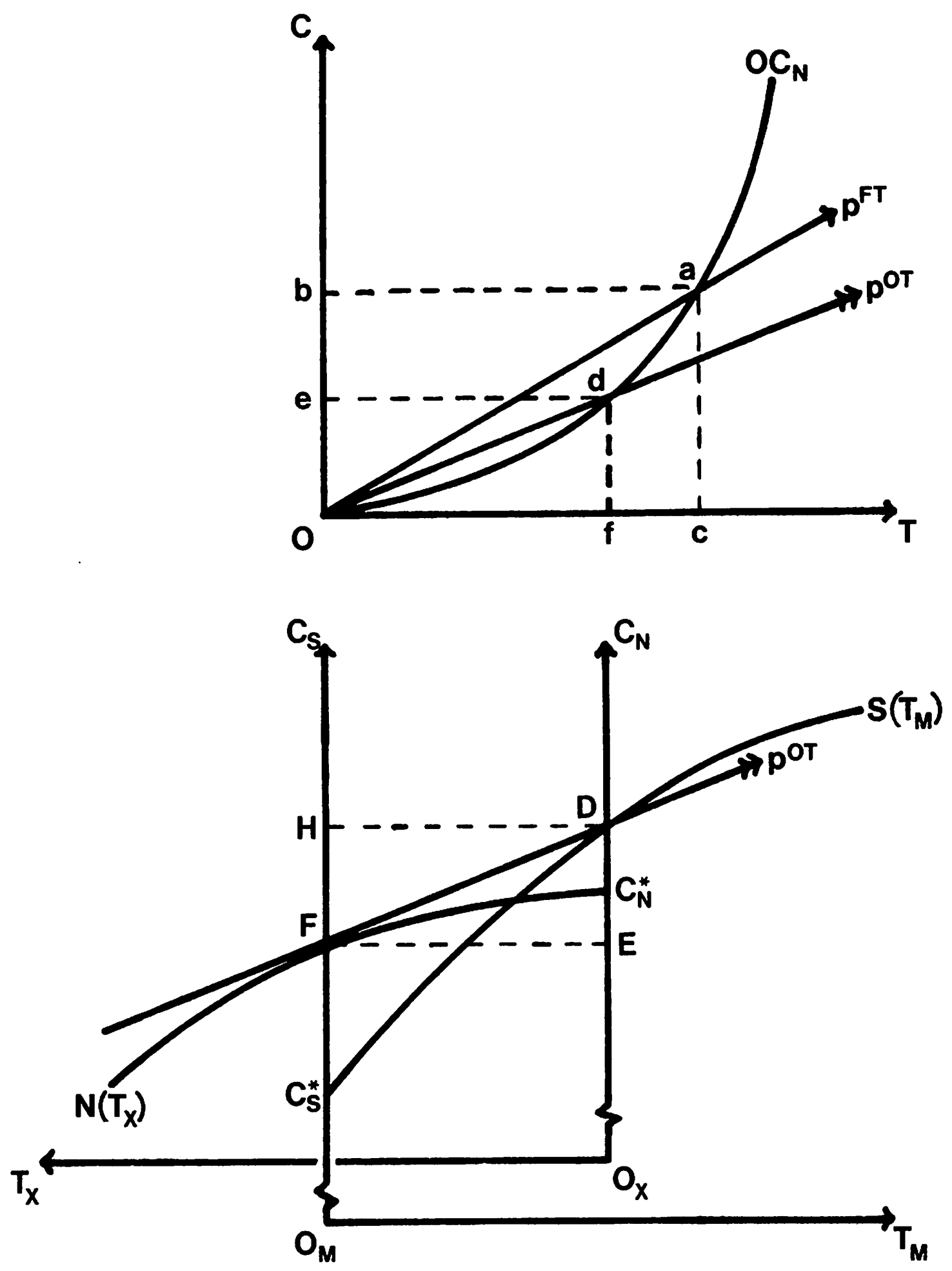

FIGURE 4(b) 
FIGURE 5(a)
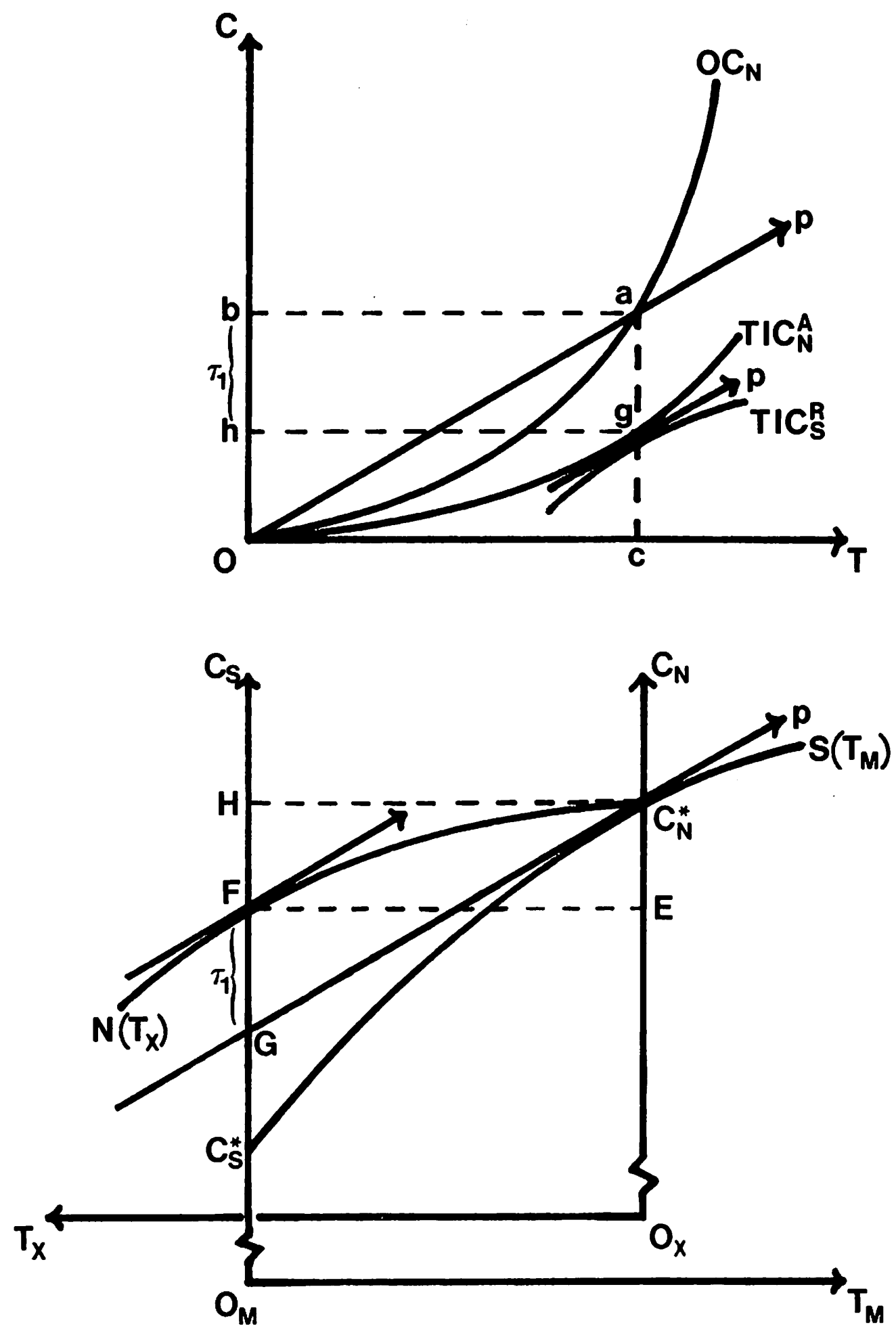

FI(NRE 5(b) 
$8101 C$

$8102 C$

$8103 C$

$8104 C$

$8105 \mathrm{C}$

$8106 C$

$8107 \mathrm{C}$

8108C D g

8109C D SU

$8110 \mathrm{C}$

$8111 C$

$8201 C$

$8202 C$

$8203 C$

$8204 C$

$8205 C$

8206C

$8207 C$

$8208 \mathrm{C}$

8209C DSU

Markusen, James R. Factor Movements and Commodity Trade as Compliments: A Survey of some Cases.

Conlon, R.M. Comparison of Australian and Canadian Manufacturing Industries: Some Empirical Evidence.

Conlon, R.M. The Incidence of Transport cost and Tariff Protection: Sme Australian Evidence.

Laidler, David. On the Case for Gradualism.

Wirick, Ronald G. Rational Expectations and Rational

stabilization Policy in an Open Economy

Mansur, Ahsan and John Whalley Numerical Secification of Applied

General Equilibrium Models: Estimation, Calibration, and Data.

Burgess, David F.. Energy Prices, Capital Formation, and Potential GNP

Jimenez, E. and Douglas H Keare. Lousing Consumption and Income in the Low Income Urban Setting: Estimates from Panel Data in El salvador

Whalley, John Labour Migration and the North-Suth Debate

Manning, Richard and John McMillan Government Expenditurei and Comparative Advantage

Freid, Joel and Peter bowitt Why Inflation Reduces Real Interest Rates

$\underline{1982}$

Manning, Richard and James R. Markusen Dynamic Non- Gbstitution and Long Run Production Possibilities

Feenstra, Robert and Ken Judd Tariffs, Technology Transfer, and Welfare

Ronald W. Jones, and Douglas D. Purvis: International Differences in Response to Common External Socks: The Role of Purchasing Power Parity

James A Brander and Barbara J. Spencer: Industrial strategy with Comnitted Firms

Whalley, John, The North-South Debate and the Terms of Trade: An Applied General Equilibrium Approach

Roger Betancourt, Christopher Clague, Arvind Panagariya CAPI TAL UTIIIZATI ON IN GENERAL EQUILIBRI UM

Mansur, Ahsan $t_{6}$ On the Estimation of I mport and Export Demand Elasticities and Elasticity Pessimism.

Whalley, J. and Randy Wigle PRICE AND QUANTITY RIGIDITIES IN ADJUSTMENT TO TRADE POLICY CHANGES: ALTERNATIVE FORMULATIONS AND INITIAL CALCULATIONS

Jimenez, E. SQUATTING AND COMMUNITY ORGANIZATION IN DEVELOPING COUNTRIES : A CONCEPTUAL FRAMEWORK 
8210C Grossman, G.M. INTERNATIONAL COMPETITION AND THE UNIONIZED SECTOR

8211C La1d1er,D. FRIEDMAN AND SCHWARTZ ON MONETARY TRENDS - A REVIEN ARTICLE

8212C Imam, M.H. and thalley, J. INCIDENCE ANALYSIS OP A SECTOR SPECIFIC MINIMUM WAGE IN A TWO SECTOR HARRIS-TODARO MODEL.

8213C Markusen, J.R. and Melvin, J.R. THE GAINS FROM TRADE THEOREM WITH INCREASING RETURNS TO SCALE.

8214C INDUSTRIAL ORGANIZATION AND THE GENERAL EQUILIBRIUM COSTS OP PROTECTION IN SMALL OPEN ECONOMIES.

8215C Laidler, D. DID MACROECONOMICS NEED THE RATIONAL EXPECTATIONS REVOLUTION?

8216C Whalley, J. and Wigle, R. ARE DEVELOPED COUNTRY MULTILATERAL TARIFP REDUCTIONS NECESSARILY BENEFICIAL FOR THE U.S.?

8217C Bade, R, and Park1n, M. IS STERLING M3 THE RIGHT AGGREGATE?

8218C Kosch, B. FIXED PRICE EQUIIIBRIA IN OPEN ECONOMIES.

1983

$8301 \mathrm{C}$ KImbell, L.J. and Harrison, G.W. ON THE SOLUTION OF GENERAL EQUILIBRIUS MODELS.

8302C Melvin, J.R. A GENERAL EQUILIBRIUM ANALYSIS OF'CANADIAN OIL POLICY.

$8303 \mathrm{C}$ Markusen, J.R. and Svensson, L.E.0. TRADE IN COODS AND FACTORS WITH INTERNATIONAL DIFFERENCES IN TECHNOLOGY.

8304C Mohammad, S. Whalley, J. RENT SEEKING IN INDIA: ITS COSTS AND POLICY SIGNIFICANCE.

8305C DSU Jimenez, E. TENURE SECURITY AND URBAN SQUATTING.

8306C Parkin, $M$. WHAT CAN MACROECONOMIC THEORY TELL US ABOUT THE WAY DEPICITS SHOULD BE MEASURED.

8307C Parkin, M. THE INFLATION DEBATE: AN ATTEMPT TO CLEAR THE AIR.

$8308 \mathrm{C}$ Wooton, I. LABOUR MIGRATION IN A MODEL OF NORTH-SOUTH TRADE.

8309C Deardorff, A.V. THE DIRECTIONS OF DEVELOPING COUNTRIES TRADE: EXANPLES FROM PURE THEORY.

8310C Manning, $R$. ADVANTAGEOUS REALLOCATIONS AND MULTIPLE EQUILIBRIA: RESULTS FOR THE THREE-AGENT TRANSFER PROBLEM. 


\author{
$8311 C$ DSU Mohammad, S. and Whalley, J. CONTROLS AND THE INTERSECTORAL TERRS OF
TRADE IN INDIA. \\ $8312 \mathrm{C}$. Brecher, Richard A. and Choudhri, Ehsan U. NEW PRODUCTS AND THE FACTOR \\ CONTENT OF INTERNATIONAL TRADE. \\ $8313 \mathrm{C}$ Jones, R.W., Neary, J.P. and Ruane, F.P. TWO-WAY CAPITAL FLOWS: CROSS- \\ HAULING IN A MDDEL OF FOREIGN INVESTMENT. \\ $8314 C$ DSU Folla1n, J.R. Jr. and J1menez, E. THE DEMAND FOR HOUSING CHARACTERISTICS
IN DEVELOPING COUNTRIES. \\ 8315C Shoven, J.B. and Whalley, J. APPLIED GENERAL EQUILIBRIUM MDDELS OF
TAXATION AND INTERNATIONAL TRADE. \\ $8316 \mathrm{C}$ Boothe, Paul and Longworth David. SOME IRREGULAR REGULARITIES IN THE \\ CANADIAN/U.S. EXCHANGE MARKET. \\ $8317 \mathrm{C}$ Hamtlton, Bob and Whalley, John. BORDER TAX ADJUSTMENTS AND U.S. TRADE. \\ $8318 \mathrm{C}$ Neary, J. Peter, and Schweinberger, Albert G. FACTOR CONTENT FUNCTIONS AND \\ THE THEORY OF INTERNATIONAL TRADE. \\ $8319 \mathrm{C}$ Veall, Michael R. THE EXPENDITURE TAX AND PROGRESSIVITY. \\ 8320C Melvin, James R. DOMESTIC EXCHANGE, TRANSPORTATION COSTS AND INTERNATIONAL \\ TRADE. \\ 8321C Hamllton, Bob and Whalley, John. GEOGRAPHICALLY DISCRIMINATORY TRADE \\ ARRANGEMENTS. \\ $8322 \mathrm{C}$ Bale, Harvey Jr. INVESTMENT FRICTIONS AND OPPORTUNITIES IN BMATERAL \\ U.S.-GANADIAN TRADE RELATIONS. \\ $8323 C$ Wonnacote, R.J. CANADA-U.S. ECONOMIC RELATIONS-A CANADIAN VIEW. \\ $8324 \mathrm{C}$ Stern, Robert M. U.S.-CANADIAN TRADE AND INVESTMENT FRICTIONS: THE \\ U.S: VIEW. \\ $8325 \mathrm{C}$ Harrison, Glenn, H. and Kimbe1l, Larry, J. HOW ROBUST IS NUMERICAL \\ GENERAL EQUILIBRIUM ANALYSIS? \\ 8326C Wonnacott, R.J. THE TASK FORCE PROPOSAL ON AUTO CONTENT: WOULD THIS \\ SIMPLY EXTEND THE AUTO PACT, OR PUT IT AT SERIOUS RISK? \\ $8327 \mathrm{C}$ Bradford, James C. CANADIAN DEFENCE TRADE WITH THE U.S. \\ Conk1 in, David. SUBSIDY PACTS. \\ Rugman, Alan M. THE BEHAVIOUR OF U.S. SUBSIDARIES IN CANADA: \\ IMPLICATIONS FOR TRADE AND INVESTMENTS.
}


8328C Boyer, Kenneth D. U.S.-CANADIAN TRANSPORTATION ISSUES.

8329C Bird, Richard M. and Brean, Donald J.S. CANADA-U.S. TAX RELATIONS: ISSUES AND PERSPECTIVES.

$8330 \mathrm{C}$ Moroz, Andrew R. CANADA-UNITED STATES AUTOMOTIVE TRADE AND TRADE POLICY ISSUES.

8331C Grey, Rodney de C. and Curt18, John. INSTITUTIONAL ARRANGaMENTS FOR U.S.-CANADIAN NEGOTIATIONS. PART I: CANADA-U.S. TRADE AND ECONOMIC ISSUES: DO WE NEED A NEW INSTITUTION? PART II: INSTITUTIONAL ARRANGEMENTS FOR MANAGING THE CANADA-U.S. ECONOMIC RELATIONSHIP.

1984

8401C Harrison, Glenn W. and Manning, Richard. BEST APPROXIMATE AGGREGATION OF INPUT-OUTPUT SYSTEMS.

8402C Parkin, Michael. CORE INFLATION: A REVIEW ESSAY.

8403C Blomquist, Ảke, and McMahon, Gary. SIMULATING COMMERICAL POLICY IN A SMALL, OPEN DUAL ECONOMY WITH URBAN UNEMPLOYMENT: A GENERAL EQUILIBRIUM APPROACH.

8404C Wonnacott, Ronald. THE THEORY OF TRADE DISCRIMINATION: THE IIIRROR IMAGE OF VINERIAN PREFERENCE THEORY?

8405C Whalley, John. IMPACTS OF A 50\% TARIFF REDUCTION IN AN EIGHT-REGION GLOBAL TRADE MODEL.

8406C Harrison, Glenn W. A GENERAL EQUILIBRIUM ANALYSIS OF TARIFT REDUCTIONS.

8407C Horstmann, Ignatius and Markusen, James R. STRATEGIC INVESTMENTS AND . THE DEVELOPMENT OF MULTINATIONALS.

8408C Gregory, Allan $\mathrm{C}$. and McCurdy, Thomas H. TESTING THE UNBIASEDNESS HYPOTHESIS IN THE FORIARD FOREIGN EXCHANGE MARKET: A SPECIPICATION ANALYSIS .

8409C Jones, Ronald W. and Klerzkowsk1, Henryk. NEIGHBORHOOD PRODUCTION STRUCTURES WITH APPLICATIONS TO THE THEORY OF INTERNATIONAL TRADE.

$8410 \mathrm{C}$ Weller, Paul and Yano, Makoto. THE ROLE OF FUTURES MARKETS IN INTERNATIONAL TRADE: A GENERAL EQ̨UILIBRIUM APPROACH.

8411C Brecher, Richard A. and Bhagwat1, Jagdish N. VOLUNTARY EXPORT RESTRICTIONS VERSUS IMPORT RESTRICTIONS: A WELFARE-THEORETIC COMPARISON. 
8412C Ethier, W11fred J. ILLEGAL IMMIGRATION.

$8413 \mathrm{C}$ Eaton, Jonathon and Gene M. Grossman. OPTIMAL TRADE AND INDUSTRIAL POLICY UNDER OLIGOPOLY.

8414C Hooton, Ian. PREFERENTIAL TRADING AGREEMENTS - A 3xn MODEL.

8415C Parkin, Michael. DISCRIMINATJNG BETWEEN KEYNESIAN AND CLASSICAL THEORIES OF THE BUSINESS CYCLE: JAPAN 1967-1982

8416C Deardorff, Alan V. FIRless FIRwoes: HOW PREFERENCES CAN INTERFERE WITH THE THEOREMS OF INTERNATIONAL TRADE.

8417C Greenwood, Jeremy. NONTRADED GOODS, THE TRADE BALANCE, AND THE BALANCE OF PAYRENTS.

8418C Blomqvist, Ake and Sharif Mohammad. CONTROLS, CORRUPTION, AND COMPETITIVE RENT-SEEKING IN LDCS.

8419C Grossman, Herschel I. POLICY, RATIONAL EXPECTATIONS, AND POSITIVE ECONOMIC ANALYSIS.

8420C Garber, Peter M. and Robert G. King. DEEP STRUCTURAL EXCAVATION? A CRITIOUUE OF EULER EQUATION METHODS.

8421C Barro, Robert J. THE BEHAVIOR OF U.S. DEFICITS.

8422C Persson, Torsten and Lars E.0. Svensson. INTERNATIONAL BORROWING AND TIME-CONSISTENT FISCAL POLICY.

8:-23C Obstfeld Maurice. CAPItal Controls, the duAl exchange rate, AND DEVALUATION.

8424C Kuhn, Peter. UNION PRODUCTIVITY EFFECTS AND ECONOMIC EFFICIENCY.

8425C Hamilton, Bob and John Whalley. TAX TREATMENT OF HOUSING IN A DYNAMIC SEOUENCED GENERAL EOUUILIBRIUM MODEL.

:426C Hamilton, Bob, Sharif Mohammad, and John Whalley. RENT SEEKING AND THE NORTH-SOUTH TERMS OF TRADE.

8427C Adams, Charles and Jeremy Greenwood. DUAL EXCHANGE RATE SYSTEMS AND CAPITAL CONTROLS: $\Lambda$ N INVESTICATION.

8428 Loh, Choon Cheong and Michael R. Veall. A NOTE ON SOCIAL SECURITY AND PRIVATE SAVINCS IN SINGAPORE.

8429 Whalley, John. REGRESSION OR PROGRESSION: THE TAXING OUESTION OF INCIDENCE ANALYSIS.

8430 Kuhn, Peter. WAGES, EFFORT, AND INCENTIVE-COMPATIBILITY IN LIFE-CYCLE EMPLOYMENT CONTRACTS. 
8431 Greenwood, Jeremy and Kent P. Kimbrough. AN INVESTIGATION IN THE THEORY OF FOREIGN EXCHANGE CONTROLS.

8432 Greenwood, Jeremy and Kent P. Kimbrough. CAPITAL CONTROLS AND THE INTERNATIONAL TRANSMISSION OF FISCAL POLICY.

8433 : Nguyen, Trien Trien and John Whalley. EỌUILIBRIUM UNDER PRICE CONTROLS WITH ENDOGENOUS TRANSACTIONS COSTS.

8434 Adams, Charles and Russell S. Boyer. EFFICIENCY AND A SIMPLE MODEL OF EXCHANSE RATE DETERMINATION.

8435 Kuhn, Peter. UNIONS, ENTREPRENEURSHIP, AND EFFICIENCY.

8436 Hercowitz, Zvi and Efraim Sadka. ON OPT MAL CURRENCY. SUBSTITUTION POLICY AND PUBLIC FINANCE.

8437 Lenjosek, Gordon and John Whalley. POLICY EVALUATION IN A SMALL OPEN PRICE TAKING ECONOMY: CANADIAN ENERGY POLICIES.

8438 Aschauer, David and Jeremy freenwood. MACROECONOMIC EFFECTS OF FISCAI POLICY.

8439C Hercowitz, Zvi. ON THE DETERMINATION OF THE EXTERNAL DEBT: THE CASE OF ISRAEL.

8440C Stern, Robert M. GLOBAL DIMENSIONS AND DETERMINANTS OF INTERNATIONAL TRADE AND INVESTMENT IN SERVICES.

$8441 \mathrm{C}$ Deardorff, Alan V. COMPARATIVE ADVANTAGE AND INTERNATIONAL TRADE AND INVESTMENT IN SERVICES.

8442C Daly, Donald J. TECHNOLOGY TRANSFER AND CANADA'S COMPETITIVE PERFORMANCE.

8443C Grey, Rodney de C. NEGOTIATING ABOUT TRADE AND INVESTMENT IN SERVICES.

8444C Grossman, Gene $M$. and Car1 Shapiro. NORMATIVE ISSUES RAISED BY INTERNATIONAL TRADE IN TECHNOLOGY SERVICES.

3445C Chant, John $\mathrm{F}$. THE CANADIAN TREATMENT OF FOREIGN BANKS: A CASE STUDY IN THE WORKINGS OF THE NATIONAL TREATMENT APPROACH.

8446C Aronson, Jonathan D. and Peter F. Cowhey. COMPUTER, DATA PROCESSING, AND COMMUNICATION SERVICES.

8447C Feketbkuty, Geza. NEGOTIATING STRATEGIES FOR LIBERALIZING TRADE AND INVESTMENT IN SERVICES.

8448C Harrison, Glenn, W. and E.E. Rutstrom. THE EFFECT OF MANUFACTURING SECTOR PROTECTION ON ASEAN AND AUSTRALIA: A GENERAL ENUUILIBRIUM ANALYSIS. 
$8501 \mathrm{C}$

8502C Horstmann, Ignatius and James R. Markusen. UP YOUR AVERAGE COST CURVE: INEFFICIENT ENTRY AND THE NEW PROTECTIONISM.

8503C Gregory, Allan $\mathrm{W}$. TESTING INTEREST RATE PARITY AND RATIONAL EXPECTATIONS TOR CANADA AND THE UNITED STATES.

8504C Kuhn, Peter and Ian Hooton. INTERNATIONAL FACTOR MOVEMENTS IN THE PRESENCE OF A FIXED FACTOR.

8505C Wong, Kar-yiu. GAINS FROM GOODS TRADE AND FACTOR MOBILITY.

8506C Weller, Paul and Makoto Yano. FUTURES MARKETS, REAL INCOME, AND SPOT PRICE VARIABILITY: A GENERAL EOUILIBRIUM APPROACH.

8507C Diewert, H.E. THE EFFECTS OF AN INNOVATION: A TRADE THEORY APPROACH.

8508C Ethier, Wilfred J. POREIGN DIRECT INVESTMENT AND THE MULTINATIONAL FIRM.

8509C Dinopoulos, Elias. INSIDE THE BLACK BOX: (IN) TANGIBLE ASSETS, INTRA-INDUSTRY INVESTMENT AND TRADE.

8510C Jones, Richard, John thalley, and Randall Higle. REGIONAL IMPACTS OF TARIFFS IN CANADA: PRELIMINARY RESULTS FROM A SMALL DIMENSIONAL NUMERICAL GENERAL EOUILIBRIUM MODEL.

8511C Whalley, John. HIDDEN CHALLENGES IN RECENT APPLIED GENERAL EOQUILIBRIUM EXERCISES.

8512C Smith, Bruce. SOME COLONIAL EVIDENCE ON TWO THEORIES OF MONEY: MARYLAND AND THE CAROLINAS.

3513C Grossman, S.J., A. Melino, and R.J. Shiller. ESTIMATING THE CONTINUOUS TIME CONSUMPTION BASED ASSET PRICING MODEL.

8514C Romer, Paul R. TAX EFFECTS AND TRANSACTION COSTS FOR SHORT TERM MARKET DISCOUNT BONDS.

8515C McCallum, Bennett T. ON CONSEỌUENCES AND CRITJCISMS OF MONETARY TARGETING.

8516C Dinopoulos, Elias and Ian Wooton. A NORTH-SOUTH MODEL OF INTERNATIONAL JUSTICE. 